\title{
PERSEPSI MASYARAKAT ACEH UTARA TERHADAP PENDIDIKAN ANAK USIA DINI
}

\author{
Elfiadi
}

Institut Agama Islam Negeri Lhokseumawe

Email: bireuenadi@gmail.com

Article received: 27 December 2018, Review process: 27 February 2019,

Article published: 30 March 2019

\begin{abstract}
This study aims to describe North Aceh's public perception of early childhood education (PAUD). The results of the study show that the people of North Aceh have a perception that: (1) (PAUD) is a level of education for children before entering primary education (SD / MI) which aims to prepare children for further education, but the community does not understand the limitations of age and type Formal and formal PAUD (2) PAUD for North Aceh Community is an education level that is very important for children because the early childhood is the most appropriate for children to grow and develop and for the introduction of religious knowledge and moral formation, (3) People assume that PAUD different from TK IRA, PAUD is only a place of care or a place to play while in kindergarten / RA which is a place of learning for children
\end{abstract}

\section{Keyword: Community Perception, Early Childhood Education}

\begin{abstract}
Abstrak
Penelitian ini bertujuan untuk mendeskripsikan persepsi masyarakat Aceh Utara terhadap pendidikan anak usia dini (PAUD). Hasil penelitian diperoleh bahwa masyarakat Aceh Utara mempunyai persepsi bahwa: (1) (PAUD) sebagai jenjang pendidikan bagi anak sebelum memasuki pendidikan dasar (SD/MI) yang bertujuan mempersiapkan anak menghadapi pendidikan selanjutnya, namun masyarakat belum memahami batasan-batasan usia serta jenis penyelenggaraan PAUD formal dan formal (2) PAUD bagi Masyarakat Aceh Utara merupakan jenjang pendidikan yang sangat penting bagi anak karena masa usia dini masa yang paling tepat bagi anak untuk tumbuh dan berkembang serta untuk pengenalan ilmu agama dan pembentukan akhlak, (3) Masyarakat beranggapan bahwa PAUD berbeda dengan TK/RA, PAUD hanya sebagai tempat penitipan atau tempat bermain sedangkan di TK/RA yang merupakan tempat belajar bagi anak.
\end{abstract}

Kata kunci: Persepsi Masyarakat, Pendidikan Anak Usia Dini (PAUD).

\section{PENDAHULUAN}

Pendidikan bagi anak sejak usia dini merupakan suatu fondasi dasar bagi pengembangan kualitas sumber daya manusia. Apabila di usia dini anak telah memperoleh layanan pendidikan yang tepat maka dapat dipastikan anak tersebut akan memiliki kesiapan 
dalam menghadapi pendidikan di jenjang selanjutnya. Penyelenggaraan pendidikan bagi anak usia dini dapat dilakukan dalam bentuk jalur pendidikan formal dan non formal. Penyelenggaraan PAUD pada jalur formal ditujukan bagi anak yang berusia 4 sampai 6 tahun meliputi Taman kanak-kanak (TK) atau Raudhatul Athfal (RA) dan lembaga sejenis lainnya. Untuk PAUD pada jalur non formal diselenggarakan oleh kelompok masyarakat atas kebutuhan dari masyarakat sendiri, meliputi Taman Penitipan Anak (TPA) yang melayani anak usia 0 sampai 2 tahun dan Kelompok Bermain (KB) melayani anak 3 sampai 4 tahun.

Berdasarkan temuan awal yang sudah berkembang dalam lingkungan masyarakat khususnya di kabupaten Aceh Utara, para orang tua masih menganggap bahwa pendidikan bagi anak sejak usia dini tidak terlalu penting. Hal ini dapat dilihat dari masih banyaknya anak-anak usia dini di kalangan masyarakat Aceh Utara yang tidak mengikuti pendidikan pada jenjang PAUD (TK/RA, TPA atau KB). Masyarakat ada yang berpendapat bahwa jenjang pendidikan awal bagi seorang anak adalah dimulai dari pendidkan dasar yaitu SD/MI, sedangkan jenjang pendidikan sebelumnya (jenjang PAUD) dianggap sebagai jenjang pendidikan yang tidak begitu penting. Masyarakat beranggapan bahwa anak-anak tidak apaapa jika tidak mengikuti jenjang pendidikan PAUD atau TK/RA, yang penting bagi anak-anak mereka adalah wajib/ harus mengikuti jenjang pendidikan awal yakni SD/MI.

Pada hakikatnya pendidikan bagi anak usia dini sangat penting karena merupakan dasar bagi pembentukan kepribadian manusia secara utuh, yaitu ditandai dengan pembentukan karakter, budi pekerti luhur, pandai, dan terampil, (Hariwijaya dan Bertiani, 2012). Untuk itu, pengalaman dan pendidikan bagi anak merupakan faktor yang paling menentukan dalam perkembangan anak itu sendiri. Isi kejiwaan anak ketika dilahirkan adalah ibarat secarik kertas yang masih kosong artinya bagaimana nanti isi dan corak kertas tersebut tergantung bagaimana cara kertas tersebut ditulisi. Istilah "tabula rasa" mengungkapkan pentingnya pengaruh pengalaman dan lingkungan hidup terhadap perkembangan anak. Anak adalah pribadi yang masih bersih dan peka terhadap rangsangan yang berasal dari lingkungan. Dengan demikian, orang tua dan pendidikan yang tepat berperan penting untuk mengisi secarik kertas kosong sehingga anak dapat berkembang secara optimal sebagaimana yang diharapkan.

Berdasarkan temuan awal dan paparan di atas, penelitian ini bertujuan untuk mengetahui persepsi masyarakat Aceh Utara terhadap pendidikan anak usia dini dalam 
memahami makna serta sudut pandang masyarakat Aceh Utara terhadap urgensi pendidikan anak usia dini.

\section{Pendidikan Anak Usia Dini}

Anak usia dini adalah sosok individu yang sedang menjalani suatu proses perkembangan yang pesat dan fundamental bagi kehidupan selanjutnya. Anak juga merupakan manusia kecil yang memiliki potensi yang masih harus dikembangkan. Menurut Santoso, pendidikan sejak taman kanak-kanak merupakan tingkatan dimulainya dasar-dasar pembentukan kepribadian anak. (Soegeng Santoso, 2014: 11). Dari pendapat ini dapat dilihat bahwa pembentukan kepribadian anak hendaknya dikembangkan sejak dini, sehingga dapat terbentuk dengan utuh setelah dewasa.

Di Indonesia, hakikat pendidikan anak usia dini di proyeksikan kedalam UU RI nomor 20 tahun 2003 tentang sistem pendidikan Nasional dalam pasal 1 ayat 14, yang berbunyi:

"Pendidikan anak usia dini adalah suatu upaya pembinaan yang ditujukan kepada anak sejak lahir sampai dengan usia enam tahun yang dilakukan melalui pemberian rangsangan pendidikan untuk membantu pertumbuhan dan perkembangan jasmani dan rohani agar anak memiliki kesiapan dalam memasuki pendidikan lanjut”.

Selanjutnya Menurut para ahli pendidikan anak usia dini yang tergabung dalam NAEYC (National Assosiation for The Education Young Children), "anak usia dini adalah sekelompok individu yang berada pada rentang usia antara 0-8 tahun (Hartati, 2007). Rentang usia ini merupakan periode yang sangat menentukan bagi perkembangan anak di tahap berikutnya. Pendidikan anak usia dini (PAUD) juga merupakan suatu upaya pemberian rangsangan dalam pendidikan, perawatan, pengasuhan yang ditujukan pada anak untuk mengembangkan seluruh potensi yang dimiliknya. Menurut Yamin (2013), "pendidikan anak usia dini adalah jendela pembuka dunia (window of opportunity) bagi anak, karena merupakan dasar dari pendidikan anak selanjutnya yang penuh tantangan dan berbagai permasalahan yang akan dihadapinya". PAUD dapat memberikan pengalaman-pengalaman belajar bagi anak yang dilakukan melalui proses bermain sehingga dapat mengoptimalkan aspek-aspek perkembangan hidupnya dengan cara yang menyenangkan. Adapun aspek perkembangan yang sangat perlu untuk dikembangkan dalam PAUD terdiri dari: kognitif, nilai agama dan moral, bahasa, fisik-motorik, dan social emosional. 
Dari paparan di atas, dapat disimpulkan bahwa pendidikan anak usia dini (PAUD) merupakan upaya pendidikan yang diberikan pada anak sejak anak lahir sampai usia delapan tahun melalui pemberian rangsangan dan pembinaan dalam rangka mengoptimalkan aspek nilai agama dan moral, kognitif, bahasa, social-emosional, serta fisik-motorik sehingga anak memiliki kesiapan dalam memasuki pendidikan lanjut.

Dalam undang-undang sistem pendidikan nasional tahun 2003 dijelaskan bahwa "(1) Pendidikan anak usia dini diselenggarakan sebelum jenjang pendidikan dasar. (2) Pendidikan anak usia dini dapat diselenggarakan melalui jalur pendidikan formal, nonformal, dan/atau informal. (3) Pendidikan anak usia dini pada jalur pendidikan formal berbentuk taman kanak-kanak (TK), Raudatul Athfal (RA), atau bentuk lain yang sederajat”. Penyelenggaraan pendidikan anak usia dini (PAUD) dapat dilakukan dalam bentuk jalur pendidikan formal, nonformal, dan informal. Penyelenggaraan PAUD pada jalur formal ditujukan bagi anak yang berusia 4 sampai 6 tahun, meliputi Taman kanak-kanak (TK) atau Raudhatul Athfal (RA) dan lembaga sejenis lainnya. Untuk PAUD pada jalur non formal diselenggarakan oleh kelompok masyarakat atas kebutuhan dari masyarakat sendiri, meliputi Taman Penitipan Anak (TPA) yang melayani anak usia 0 sampai 2 tahun, Kelompok Bermain (KB) melayani anak 3 sampai 4 tahun. Sedangkan untuk PAUD informal adalah pendidikan bagi anak yang dilakukan oleh keluarga atau lingkungan anak itu sendiri, yang bertujuan memberikan keyakinan agama, menanamkan nilai budaya, nilai moral, etika dan kepribadian, estetika serta meningkatkan pengetahuan dan keterampilan anak dalam rangka mencapai tujuan pendidikan nasional.

Pendidikan anak usia dini bertujuan untuk mengembangkan seluruh potensi anak agar memiliki kesiapan dalam menghadapi pendidikan selanjutnya. Anak dapat dipandang sebagai individu yang baru mengenal dunia. Anak perlu di bimbing agar mampu memahami berbagai hal tentang dunia dan isinya. Anak juga perlu dibimbing agar memahami berbagai fenomena alam dan dapat melakukan keterampilan-keterampilan yang dibutuhkan untuk hidup dimasyarakat. Interaksi anak dengan benda dan dengan orang lain diperlukan untuk anak belajar agar anak mampu mengembangkan kepribadian, watak dan akhlak yang mulia. Karena usia dini merupakan saat yang sangat berharga untuk menanamkan nilai nasionalisme, kebangsaan, agama, etika, moral, norma sosial yang berguna untuk kehidupannya dan strategi bagi pengembangan suatu bangsa. Selain itu juga dengan mengikuti jenjang pendidikan 
PAUD, anak akan memiliki kesiapan baik fisik maupun mental dalam memasuki pendidikan pada jenjang selanjutnya.

\section{Persepsi}

Persepsi seseorang dapat timbul dari pengalaman yang telah diperolehnya, baik yang dilakukan sendiri maupun kesan dari orang lain. Menurut Sugihartono (2013) mengemukakan bahwa persepsi adalah kemampuan otak dalam menerjemahkan stimulus atau proses untuk menerjemahkan stimulus yang masuk ke dalam alat indera manusia. Suharman (2005), menyatakan bahwa "persepsi merupakan suatu proses menginterpretasikan atau menafsir informasi yang diperoleh melalui sistem alat indera manusia”. Persepsi merupakan salah satu aspek psikologis yang penting bagi manusia dalam merespon kehadiran berbagai aspek dan gejala di sekitarnya. Persepsi mengandung pengertian yang sangat luas, menyangkut intern dan ekstern. Menurut Kamus Besar Bahasa Indonesia (KBBI), persepsi adalah tanggapan (penerimaan) langsung dari sesuatu. Proses seseorang mengetahui beberapa hal melalui panca inderanya.

Persepsi manusia terhadap sesuatu dapat berbeda-beda berdasarkan sudut pandang dalam penginderaannya. Ada yang mempersepsikan sesuatu itu baik atau persepsi yang positif maupun persepsi negatif yang akan mempengaruhi tindakan manusia yang tampak atau nyata. Perbedaan tersebut bisa dipengaruhi oleh banyak faktor, diantaranya adalah pengetahuan, pengalaman dan sudut pandangnya. Selanjutnya menurut Walgito mengungkapkan bahwa persepsi merupakan suatu proses pengorganisasian, penginterpretasian terhadap stimulus yang diterima oleh organisme atau individu sehingga menjadi sesuatu yang berarti, dan merupakan aktivitas yang integrated dalam diri individu. Respon sebagai akibat dari persepsi yang dapat diambil oleh individu dengan berbagai macam bentuk. Setiap orang mempunyai kecenderungan dalam melihat benda yang sama dengan cara yang berbeda-beda. Persepsi juga bertautan dengan cara pandang seseorang terhadap suatu objek tertentu dengan cara yang berbeda-beda dengan menggunakan alat indera yang dimiliki, kemudian berusaha untuk menafsirkannya. Persepsi juga merupakan hasil kerja otak dalam memahami atau menilai suatu hal yang terjadi di sekitarnya (Rahmat, 2010). Dengan kata lain, persepsi adalah tanggapan dari hasil pengamatan tentang suatu objek atau peristiwa yang diperoleh dengan menyimpulkan informasi dan menafsirkan pesan. Akumulasi dari persepsi akan mampu membentuk suatu opini asumsi atau kesimpulan tentang sesuatu yang telah dialaminya. 
Dari paparan di atas dapat disimpulkan bahwa persepsi merupakan suatu tanggapan atau proses penafsiran informasi yang diperoleh berdasarkan pengetahuan, pengalaman, penginderaan sehingga membentuk suatu asumsi atau kesimpulan tentang sesuatu yang telah dialaminya. Secara umum dapat disimpulkan bahwa persepsi masyarakat merupakan suatu tanggapan atau proses penafsiran informasi oleh sekelompok manusia yang hidup bersama tentang sesuatu yang telah dialaminya berdasarkan pengetahuan, pengalaman, penginderaannya sehingga dapat membentuk suatu asumsi atau kesimpulan terhadap sesuatu. Adapun persepsi masyarakat yang dimaksud dalam penelitian ini adalah berkaitan dengan tanggapan atau penafsiran masyarakat mengenai pendidikan anak usia dini (PAUD).

\section{METODOLOGI}

Jenis penelitian menggunakan pendekatan kualitatif. Penelitian ini dilakukan di Kabupaten Aceh Utara Provinsi Aceh. Subyek penelitian ini yakni masyarakat Aceh Utara yang terdiri dari para guru PAUD, para orang tua yang memiliki anak usia dini yang tersebar di kecamatan Nisam, Matang Kuli, Meurah mulia, Sawang dan Syamtalira Bayu. Teknik pengumpulan data menggunakan teknik wawancara.

Teknik analisis data menggunakan teknik analisis data kualitatif. Menurut Moleong (2007), teknik analisis kualitatif dilakukan dengan menyajikan data yang dimulai dengan menelaah seluruh data terkumpul dan menyusunnya dalam satu satuan. Menurut Miles dan Huberman (2007), terdapat tiga teknik analisisi data kualitatif yaitu reduksi data, penyajian data dan penarikan kesimpulan.

\section{HASIL DAN PEMBAHASAN}

\section{Pemahaman Masyarakat Aceh Utara terhadap Pendidikan Anak Usia Dini}

Hasil wawancara dengan para guru PAUD diperoleh data bahwa PAUD merupakan tempat belajar bagi anak sebelum mereka masuk ke jenjang pendidikan dasar (SD/MI). Sebagian besar para guru PAUD sudah memahami tentang makna PAUD, menurut mereka PAUD adalah salah satu bentuk dari jenjang pendidikan bagi anak usia dini di mulai dari usia tiga tahun. Pernyataan ini senada dengan pendapat yang dikemukakan oleh salah seorang guru PAUD di kecamatan Nisam, "di sekolah TK kami hanya menerima anak-anak yang berusia empat sampai enam tahun, untuk anak usia nol sampai tiga tahun itu di antarkan ke PAUD karena di PAUD di daerah sini menerima anak-anak yang berusia di bawah empat tahun atau usia sebelum TK”. 
Dari informasi di atas dapat dijabarkan bahwa para guru PAUD sudah dapat memahami mengenai rentang usia untuk sekolah TK/RA. Namun demikian mereka belum dapat memahami secara spesifik tentang batasan usia PAUD pada hakikatnya. Hal ini di karenakan karena para guru PAUD masih menganggap TK/RA bukan bagian dari PAUD, padahal PAUD terbagi kedalam jalur formal dan non formal. PAUD jalur formal yakni berbentuk program TK/RA sedang PAUD non formal berbentuk program TPA (taman penitipan anak) dan KB (kelompok Bermain) yang melayani usia dari nol sampai empat tahun.

Berdasarkan temuan di atas dapat jelaskan bahwa menurut masyarakat Aceh Utara, PAUD itu merupakan sebatas tempat anak-anak bermain atau sejenis tempat penitipan biasa. Menurutnya PAUD bukan tempat anak memperoleh pembelajaran sebagaimana sekolah lainnya. Di TK/ RA anak-anak baru akan mengukuti pembelajaran-pembelajaran yang bermanfaat bagi persiapan masuk SD.

\section{Sudut pandang masyarakat Aceh Utara terhadap urgensi PAUD}

Berdasarkan temuan di lapangan bahwa, pendidikan bagi anak sejak usia dini merupakan pendidikan yang penting bagi seorang anak. Beberapa guru PAUD juga berpendapat sangat penting anak-anak mengikuti pendidikan di usia dini. Hal ini dikarenakan karena di usia dini merupakan usia yang sangat efektif dalam memberikan pendidikan kepada anak. Anak usia dini sangat mudah memahami bahkan mengingat apa saja yang akan di pelajarinya. Sehingga dengan mendapatkan pendidikan yang tepat di usia dini akan bermanfaat bagi anak dalam membentuk dan mengembangkan karakter serta kepribadiannya demi kesuksesan di masa depan. Hal ini sebagaimana petikan wawancara dengan guru PAUD mengatakan bahwa "pendidikan yang ditempuh oleh seorang anak pada usia dini dapat menjadi bekal dalam membentuk karakter dan kepribadian anak. Anak-anak yang memperoleh pendidikan di usia dini akan lebih sukses di masa mendatang di banding dengan anak yang tidak memperoleh pendidikan di usia dini”.

Berdasarkan hasil wawancara dengan beberapa orang tua juga menyebutkan bahwa pendidikan bagi anak sejak usia dini merupakan hal yang sangat penting. Menurut para orang tua tersebut masa usia dini masa yang paling bagus untuk memberikan pendidikan bagi anak, hal ini dikarenakan anak akan lebih mudah di bentuk dan penurut saat usia dini dibandingkan dengan usia remaja. Pendidikan yang diberikan sejak dini juga akan memberikan bekal 
pengalaman awal bagi anak untuk menghadapi tantangan di masa berikutnya. Salah satu kutipan wawancara dengan seorang orangtua menuturkan bahwa "bagi saya selaku orang tua tentu mengharapkan anak-anak tumbuh dan berkembang menjadi orang yang dapat berguna bagi agama, nusa dan bangsa, dan oleh karena itu, dari kecillah perlu kita bimbing dengan benar sehingga akan menjadi anak-anak yang pandai.".

Para guru PAUD dan juga para orang tua menyepakati bahwa pendidikan bagi anak sejak usia dini merupakan hal yang sangat penting. Melalui lembaga-lembaga PAUD anakanak usia dini akan di didik menjadi seseorang yang tumbuh dan berkembang menjadi pribadi yang unggul sehingga dapat menjadi generasi penerus di masa mendatang.

\section{Pemahaman masyarakat tentang konsep dasar PAUD}

Pemahaman masyarakat Aceh Utara terhadap konsep dasar pendidikan anak usia dini yakni mereka berpendapat bahwa PAUD berbeda dengan TK/RA. pemahaman para guru PAUD terhadap usia anak pada jenjang TK/RA semua menyatakan bahwa usia anak yang dilayani pada jalur TK/RA adalah 4 sampai 6 tahun. Hal ini sebagaimana hasil wawancara dengan salah satu guru PAUD yang mengatakan "TK dan $R A$ merupakan jenjang pendidikan yang sama-sama melayani usia 4 sampai 6 tahun dan tidak ada perbedaan keduanya, hanya saja naungan kementerian yang berbeda, TK di bawah Kementerian Pendidikan sedangkan $R A$ di bawah kementerian Agama". Sudut pandang para orang tua yang memiliki anak usia dini yang juga berpendapat sama dengan apa yang disampaikan oleh para guru PAUD. Namun ada sebagian orang tua yang berpendapat bahwa perbedaan PAUD dengan TK adalah pada materi pelajarannya, dimana di TK anak-anak belajar membaca, menulis dan berhitung sedangkan PAUD adalah tempat penitipan dan bermain bagi anak-anak. Para guru di lembaga PAUD mengajarkan materi kepada anak-anak yang sesuai dengan kebutuhan anak sehari-hari sehingga dapat menjadi bekal bagi anak dalam menghadapi pendidikan di usai selanjutnya. Hasil wawancara dengan salah seorang guru PAUD mengatakan bahwa "di TK/RA kami materi yang kami ajarkan adalah menargetkan anak untuk bisa membaca, menulis dan berhitung dan ini merupakan tuntutan para orang tua untuk membuat anak-anak mereka dapat menguasai kemampuan tersebut demi menyesuaikan dengan kebutuhan anak di SD nantinya". Materi yang di ajarkan pada PAUD dengan menyesuaikan dengan kebutuhan anak di sekolah dasar dan juga memenuhi permintaan para orang tua untuk bisa anak membaca, menulis dan berhitung. Secara umum para masyarakat belum memahami dengan benar 
mengenai apasaja materi atau capaian pembelajaran yang seharusnya di ajarkan kepada anak di usia dini sebagaimana yang terdapat dalam kurikulum PAUD

\section{SIMPULAN}

Masyarakat di Kabupaten Aceh Utara memaknai pendidikan anak usia dini (PAUD) sebagai suatu jenjang pendidikan yang ditempuh anak sebelum mereka memasuki pendidikan dasar (SD/MI) yang bertujuan mempersiapkan anak menghadapi pendidikan selanjutnya. Namun ada juga sebagian masyarakat yang menganggap PAUD sebagai pendidikan yang melayani anak-anak sebelum usia TK/RA. Secara spesifik masyarakat Aceh Utara yang terdiri dari guru dan orang tua dari anak usia dini belum memahami mengenai batasan usia serta pembagian dari jenjang PAUD itu sendiri yang terdiri dari PAUD formal dan formal. Masyarakat menganggap bahwa PAUD dengan TK berbeda, belum memahami bahwa TK/RA adalah bagian dari PAUD. Masyarakat berpemahaman bahwa PAUD tempat bermain sedangkan di TK/RA baru tempat anak belajar.

Persepsi masyarakat Aceh Utara terhadap pendidikan bagi anak sejak usia dini merupakan suatu hal yang sangat penting dan PAUD merupakan pendidikan utama bagi anak sebelum mereka mengikuti pendidikan di jenjang selanjutnya. Menurut masyarakat, PAUD itu sangat penting dikarenakan pada masa usia dini adalah masa yang sangat potensial dalam pertumbuhan dan perkembangan anak yang akan berdampak pada kehidupan anak di masa mendatang. Di usia dini juga masa yang paling tepat untuk pengenalan ilmu agama dan pembentuka akhlak anak. Selain itu, masyarakat Aceh Utara sangat mendukung jika seandainya anak-anak diwajibkan masuk PAUD atau TK terlebih dahulu baru kemudian boleh masuk $\mathrm{SD} / \mathrm{MI}$.

Pemahaman masyarakat Aceh Utara terhadap konsep dasar Pendidikan Anak Usia Dini adalah masih keliru. Mereka menganggap lembaga-lembaga PAUD hanya sebagai tempat penitipan dan tempat anak-anak bermain saja sedangkan di TK/RA pemahaman masyarakat adalah tempat anak-anak belajar kegiatan seperti membaca, menulis, berhitung, bernyanyi, mewarnai, bercerita. Masyarakat menganggap di lembaga PAUD bahkan TK tidak memiliki capaian pembelajaran atau kurikulum sebagaimana layaknya pendidikan formal lainnya. Masyarakat belum memahami bahwa sebenarnya tujuan pendidikan bagi anak sejak usia dini adalah untuk mengembangkan seluruh aspek-aspek perkembangan anak yang terdiri dari nilai agama dan moral, fisik-motorik, kognitif, bahasa, sosial emosional, dan seni. 


\section{DAFTAR PUSTAKA}

Dirjen PAUDNI. 2011. Kerangka Besar Pembangunan PAUD Indonesia Periode 2011-2025. Jakarta: Dirjen PAUDNI Kemendikbud.

Hartati, Sofia. How to Be a Good Teacher and How to be a Good Mother. Jakarta: Enno Media.

Hariwijaya dan Bertiani Eka Sukaca. 2012. PAUD Melejitkan Potensi Anak dengan Pendidikan Sejak Dini. Yogyakarta: Pustaka Belajar.

Moleong, Lexy J. 2007. Metodologi Penelitian Kualitatif. Bandung: Remaja Rosdakarya.

Morrison, Goerge.2012. Dasar-dasar Pendidikan Anak Usia Dini. Jakarta: Indeks

Miles dan Huberman. 2007. Analisis Data Kualitatif, Buku Sumber Tentang Metode-Metode Baru. Jakarta: UI Press.

UU sistem Pendidikan Nasional Nomor 20 tahun 2003 Pasal 28 ayat 1 sampai ayat 3

Peraturan Pemerintah No. 17 Tahun 2010 tentang Pengelolaan PAUD, pasal 61

Peraturan Menteri Pendidikan dan Kebudayaan nomor 58 tahun 2009. Standar Pendidikan Anak Usia Dini.

Peraturan Menteri Pendidikan dan Kebudayaan nomor 146 tahun 2013. Kurikulum PAUD 2013.

Rahmat, Jalaluddin. 2010. Psikologi Komunikasi Edisi Revisi. Bandung: Remaja Rosdakarya.

Sugiyono. 2006. Metode Penelitian Kuantitatif, Kualitatif dan $R \&$ \& . Bandung:Alfabeta.

Santoso, Soegeng. 2004. Pendidikan Anak Usia Dini. Jakarta: Citra Pendidikan.

Sugihartono, dkk. 2013. Psikologi Pendidikan.Yogyakarta: UNY.

Suharman. 2005. Psikologi Kognitif. Jakarta: Aneka Karyacipta.

Walgito, Bimo. Pengantar Psikologi Umum. Yogyakarta: Penerbit Andi.

Yamin, Martinis dan Jamilah Sabri. 2013. Panduan Pendidikan Anak Usia Dini. Jakarta: Referensi. 